\title{
Kontur Tekanan dan Kecepatan Aliran Fluida Pada Pompa Hydraulic-Ram
}

\author{
(Pressure and Velocity Contours of Fluid Flow on Hydraulic-Ram Pump)
}

Sukamta $_{a, b, c, d, e}$, Binanda Braja Mahendra $\mathbf{S}^{\text {b }}$, Krisdiyanto $^{\text {c }}$, Ongky Janalto ${ }^{\text {d }}$, Wursito Adi Priambodo ${ }^{\text {e }}$
Studi Teknik Mesin, Fakultas Teknik, Universitas Muhammadiyah Yogyakarta
Jl. Brawijaya, Kasihan, Bantul, Yogyakarta 55183
email: sukamta@umy.ac.id, binandabraja123@gmail.com, krisdyanto@umy.ac.id, ongki2101@gmail.com' wursito.adi.2015@ft.umy.ac.id

\begin{abstract}
Abstrak
Karakteristik aliran fluida sangatlah penting diprediksi agar dapat dilakukan upaya pencegahan dini terhadap kerusakan yang terjadi pada saluran perpipaan. Salah satu metode yang tepat untuk memprediksi karakteristik aliran tersebut adalah Computational Fluid Dynamics (CFD). Metode ini sangat cocok digunakan untuk melakukan analisis sebuah sistem yang rumit dan sulit dipecahkan dengan perhitungan manual. Penelitian ini dilakukan untuk mengetahui fenomena aliran yang terjadi pada pompa Hydram dengan simulasi numerik menggunakan software ANSYS Fluent 19 R2 academic. Simulasi ini dilakukan pada pompa Hydram berdiameter tabung 8 inch dan panjang pesat 7,3 m. Simulasi pada kondisi transien ini dilakukan dengan menggunakan metode layering mesh dinamis. Hasil simulasi menunjukkan karakteristik aliran fluida di dalam pompa Hydram dengan kontur tekanan yang tidak merata tetapi terkonsentrasi pada titik tertentu. Tekanan di area badan pompa lebih tinggi daripada di area tabung, perbedaan tekanan disebabkan oleh gerakan katup dan perbedaan diameter pipa. Kecepatan aliran pada pipa pesat sangat berpengaruh pada tekanan yang dihasilkan, dan hal ini akan mempengaruhi head pompa Hydram juga akan meningkat.
\end{abstract}

Kata kunci : Fluida, hydraulic-ram, komputasi, pompa, simulasi.

\begin{abstract}
It is important to predict the characteristics of the fluid flow so that early prevention efforts can be made. An appropriate method for predicting the flow characteristics is Computational Fluid Dynamics (CFD). This method is suitable for analyzing complex systems that are difficult to solve using manual calculations. This research was conducted to determine the flow phenomenon that occurs in Hydram pumps with numerical simulations using ANSYS Fluent 19 $\mathrm{R} 2$ academic software. This simulation was carried out on a Hydram pump with a diameter of 8 inches and a pipe length of $7.3 \mathrm{~m}$. Simulations on these transient conditions are carried out using the layering dynamic mesh method. The simulation result in the fluid flow characteristics at Hydram pump with uneven pressure contours but concentrated at a certain point. Pressure in the pump body area is higher than that in the tube area, the pressure difference is caused by the movement of the valve and the difference in pipe diameter. The flow velocity on the pipe is very fast influencing the pressure generated, and this will affect the Hydram pump head will also increase.
\end{abstract}

Keywords: Computational, fluid, Hydraulic-ram, pump, simulation.

\section{Pendahuluan}

Air merupakan salah satu kebutuhan pokok makhluk hidup termasuk manusia. Air memiliki peran penting dalam kelangsungan hidup manusia, seperti memenuhi kebutuhan rumah tangga, irigasi pertanian, irigasi perikanan, dan kebutuhan lainnya. Daerah pedesaan masih mengalami kesulitan dalam memenuhi kebutuhan air, terutama daerah yang memiliki geografis lebih tinggi dibandingkan sumber air nya. Pompa merupakan solusi yang tepat untuk memenuhi kebutuhan air. Jenis pompa yang biasa digunakan adalah pompa listrik 
konvensional yang menggunakan motor listrik sebagai sumber tenaganya. Namun demikian, pompa konvensional tidak efisien dan ekonomis jika digunakan di daerah yang sumber energi listriknya terbatas. Untuk daerah semacam ini diperlukan pompa dengan biaya operasional murah dan perawatan juga mudah.

Pompa yang tidak membutuhkan energi listrik sebagai sumber tenaganya adalah pompa hidaulic ram (Hydram). Pompa Hydram merupakan pompa ramah lingkungan dibandingkan dengan pompa konvensional atau pompa energi berbasis bahan bakar fosil. Air limbah dari pompa Hydram dapat dengan mudah di manfaatkan kembali kedalam reservoir. Pompa Hydram memanfaatkan tekanan air sebagai sumber tenaga. Prinsip kerja pompa Hydram menggunakan pemanfaatan gravitasi dimana akan menciptakan energi dari hantaman air yang kemudian mendorong air ke tempat yang lebih tinggi. Menurut Widiarto dan Sudarto (1996) untuk mendapatkan energi potensial dari hantaman air diperlukan syarat utama yaitu harus ada terjunan air yang dialirkan melalui pipa miring atau penstock dengan beda tinggi elevasi dengan pompa Hydram minimal $1 \mathrm{~m}$. [1]. Peneliti sebelumnya, Marbun \& Hazwi [2] melakukan CFD aliran fluida pada pompa Hydram dengan tinggi air jatuh 2,3 m. Simulasi yang digunakan adalah untuk aliran steady, inkompresible, turbulen dan geometri yang digunakan pada penelitian tersebut geometri 3 tiga dimensi. Hasil simulasi dilakukan validasi dengan membandingkan hasil simulasi dengan hasil eksperimen. Hasil simulasi didapat penyimpangan terendah sebesar $0,78 \%$ dan penyimpangan tertinggi sebesar 9,19 $\%$. Peneltian terdahulu juga telah menyajikan analisis kinerja pompa ram hidrolik menggunakan computational fluid dynamic (CFD). Studi ini menetapkan bahwa aliran massa melalui katup limbah Hydram lebih banyak, sehingga untuk menguranginya dilakukan peningkatan dan desain baru dibuat. Ini didasarkan pada studi sistematis pompa Hydram dan pengujian model pompa Hydram. Hasilnya juga telah dianalisis dan dibandingkan dengan tinjauan literatur penelitian sebelumnya[3]

Sementara itu Siahaan, dkk. (2013) melakukan penelitian untuk mengetahui pengaruh variasi panjang pesat dan diameter chamber terhadap efisiensi pompa Hydram. Pompa Hydram yang digunakan dalam penelitian ini memiliki diameter driven pipe 1,5 inch dan diameter delivery pipe 0,5 inch, dengan variasi panjang driven pipe adalah $8 \mathrm{~m}, 10 \mathrm{~m}$, dan $12 \mathrm{~m}$. Sedangkan variasi diameter air chamber yang digunakan adalah 3 inch, dan 4 inch. Hasil penelitian menunjukkan bahwa efisiensi maksimum diperoleh pada variasi panjang driven pipe $8 \mathrm{~m}$ dan diameter air chamber 3 inch, yaitu sebesar 37\%.[4]

Sementara itu, telah dilakukan penelitian yang bertujuan untuk mengetahui pengaruh volume tabung udara terhadap efisiensi pompa Hydram dengan menggunakan dua buah tabung udara yang panjangnya 400 dan $600 \mathrm{~mm}$ dengan diameter $60 \mathrm{~mm}$, sehingga dihasilkan volume 1,13 dan 1,70 liter. Berat katup buang dan hantar masing- masing 760 dan 39 gram. Head suplai diposisikan pada ketinggian $1 \mathrm{~m}$, sedangkan head hantar pada ketinggian $3 \mathrm{~m}$. Hasil penelitian menunjukkan memperbesar volume tabung udara dapat meningkatkan efisiensi[5]. Sebelumnya juga telah dilakukan perancangan pompa Hydram dengan menggunakan variasi tinggi tabung udara dengan tinggi $40 \mathrm{~cm}$ dan $60 \mathrm{~cm}$ dengan diameter $6.35 \mathrm{~cm}$ serta variasi panjang pipa pemasukan $8 \mathrm{~m}, 10 \mathrm{~m}$ dan $12 \mathrm{~m}$. Tinggi saluran suplai 2,3 meter dan tinggi saluran tekan $8 \mathrm{~m}$. Dari perhitungan di dapat kapasitas pompa maksimum sebesar $3,46666 \times 10^{-5} \mathrm{~m} 3 / \mathrm{s}$. Efesiensi maksimum pompa Hydram $29,55 \%$ pada tinggi tabung $60 \mathrm{~cm}$ dan panjang pipa masuk $10 \mathrm{~m}$ [6]. Sedangkan penelitian untuk mengetahui pengaruh jarak sumbu katup limbah dengan sumbu tabung udara terhadap debit air keluaran (output) dan efisiensi yang dihasilkan juga telah dilakukan[7]. Metode yang digunakan adalah dengan melakukan pengujian dengan variasi jarak sumbu katup limbah dengan sumbu tabung udara sepanjang $0,25 \mathrm{~m}, 0,35 \mathrm{~m}$, dan $0,45 \mathrm{~m}$ dan menggunakan katup limbah berdiameter 4 inchi. Proses pengujian pada tinggi terjunan air masuk 1,7 m, diameter pipa air masuk 6 inchi dengan debit input $0,084 \mathrm{~m}^{3} /$ detik dan tinggi angkat air $5 \mathrm{~m}$ 
dengan panjang pipa penghantar $50 \mathrm{~m}$. Hasil penelitian menunjukkan bahwa pada variasi jarak yang semakin kecil akan menghasilkan debit yang semakin besar dan sebaliknya. Penelitian unjuk kerja pompa Hydram menggunakan kompresor tabung berdiameter tabung 3 inci dan tinggi $25 \mathrm{~cm}$ telah dilakukan[7]. Level air yang digunakan berada pada posisi 5 meter dengan ketinggian 8 meter. Parameter yang diamati adalah tekanan input, tekanan keluaran, tekanan kompresor tabung, tekanan limbah katup, input pembuangan air, aliran air keluaran dan efisiensi pompa. Hasil penelitian menunjukkan bahwa posisi pompa Hydram, dengan konfigurasi tabung kompresor paralel memiliki kinerja yang lebih baik daripada konfigurasi seri tabung kompresor, dimana head maksimum mencapai 22 meter, debit 0,0453 liter/detik dan efisiensi sebesar 3,278\%. Selaras deng peneliti sebelumnya, penelitian untuk mengetahui unjuk kerja pompa hidrolik ram dengan variasi berat katup buang dan head input juga telah dilakukan[8]. Pompa hidrolik ram yang digunakan berdiameter pipa masuk 1,5 inch dan diameter pipa keluar 0,5 inch. Variasi berat katup limbah yang dipakai adalah $410 \mathrm{~g}, 450 \mathrm{~g}, 490 \mathrm{~g}, 540 \mathrm{~g}, 580 \mathrm{~g}$ dan $630 \mathrm{~g}$. Hasil penelitian menunjukkan bahwa kapasitas aliran maksimum, maksimum head discharge dan efisiensi maksimum dicapai pada berat katup limbah $410 \mathrm{~g}$. Kapasitas aliran maksimum adalah $11,146 \times 10-5 \mathrm{~m}^{3} / \mathrm{s}$, maksimum head discharge adalah 7,378 m dan eficiensi maksimum adalah $16,302 \%$. Sementara, terdapat pula penelitian sebelumnya yang bertujuan menganalisa pengaruh variasi tabung angin dan diameter pipa inlet terhadap debit pompa Hydram yang dihasilkan. Instalasi pompa Hydram menggunakan diameter pipa inlet 2 inchi dan pengaruh 3 variasi tabung udara 2 inch, 3 inchi, 4 inch. Hasil penelitian menunjukkan bahwa penggunaan tabung udara dapat memperbesar head output pompa Hydram, efisiensi pompa Hydram, dan debit air yang dihasilkan. Demikian pula besarnya tekanan pada waste valve sangat berpengaruh pada ketinggian yang dicapai dan debit air yang di hasilkan[9]. Pengaruh faktor volume tabung udara dan beban katup limbah pompa Hydram terhadap efisiensi serta pengaturan paling optimal untuk mendapatkan efisiensi terbaik telah dilakukan pula oleh peneliti sebelumnya[10]. Dari hasil percobaan dan analisa varians serta regresi response surface diperoleh hasil bahwa faktor volume tabung udara dan beban katup limbah berpengaruh pada efisiensi pompa, begitu pula interaksi antara kedua faktor. Pengaturan optimal untuk mendapatkan efisiensi terbaik adalah saat volume tabung $1300 \mathrm{ml}$ dan beban 400 gram untuk mendapatkan efisiensi $42,92 \%$. Penelitian dilakukan untuk mengetahui kenaikan tekanan yang disebabkan oleh water hammer di instalasi ram hidrolik dengan dan tanpa bejana udara[11]. Hasil penelitian ini menunjukkan bahwa back head bertekanan yang disebabkan oleh water hammer pada drive pipe menurun dari 103,87 m (tanpa bejana udara) dan $37,85 \mathrm{~m}$ (dengan bejana udara).

Perlu dilakukan prediksi dan analisis aliran fluida pada pompa Hydram untuk mengetahui karakteristik aliran fluida yang terjadi. Memprediksi aliran fluida pada pompa Hydram salah satunya dapat menggunakan metode berbasis komputer. Metode berbasis komputer yang dapat digunakan untuk simulasi aliran fluida salah satunya CFD (Computational Fluid Dynamics). Walaupun penelitian CFD pada aliran fluida pada pompa Hydram ini hanya menggunakan software ANSYS Fluent 19 R2 Academic, namun telah mampu mensimulasikan proses aliran fluida yang terjadi pada pompa hydram tersebut. Hasil CFD ini menghasilkan data berupa kontur, grafik, kurva, vektor dan animasi yang menunjukan karakteristik dari suatu aliran fluida. Inilah keunggulan dari metode ini, sehingga akan lebih mudah dilakukan analisis terhadap karakteristik aliran fluida yang terjadi pada pompa Hydram. Hasil ini analisis terhadap karakteristik aliran fluida ini dapat menjadi pertimbangan untuk meningkatkan performance sebuah pompa hydram atau melakukan inovasi lainnya. 


\section{Metode}

Simulasi yang digunakan pada penelitian ini menggunakan Ansys Fluent pada kondisi transient. Geometri pompa Hydram digambar dengan skala 1:1. Penelitian ini menggunakan geometri pompa Hydram dalam bentuk 3 dimensi CAD. Berikut ini gambar geometri 3 dimensi pompa Hydram, dengan panjang pada pipa miring 7,3 m, diameter tabung 8 inch, diameter pipa 4 inch seperti yang ditunjukan pada gambar 2.1 .

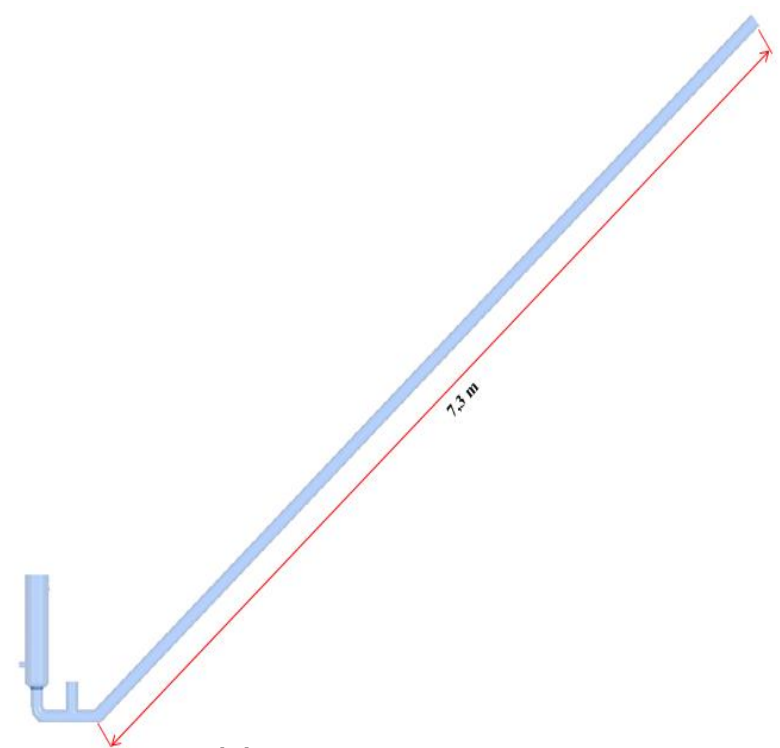

(a)

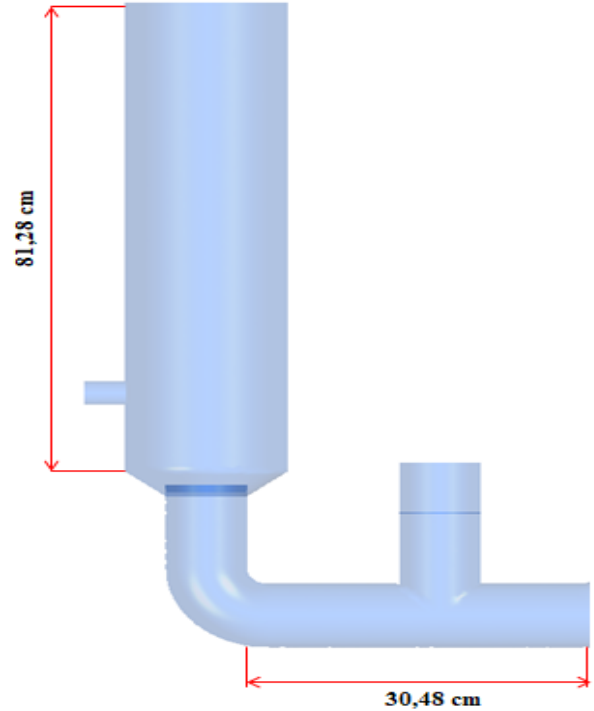

(b)

Gambar 2.1 (a). Geometri Pompa Hydram dan Pipa Pesat, (b). Geometri Pompa Hydram

Mesh yang digunakan pada simulasi ini menggunakan jenis tetrhedral mesh, refinement mesh dilakukan menggunakan metode body influence serta penerapan $y+$ atau inflation diseluruh geometri pompa Hydram untuk mendapatkan hasil yang baik didaerah sekitar wall, seperti yang ditunjukkan pada Gambar 2.2. Simulasi menggunakan model viscous k-omega standart dijalankan dalam kondisi transient dan solution scheme menggunakan jenis Coupled, dengan debit aliran pada sisi masuk sebesar 6.01 liter/detik.

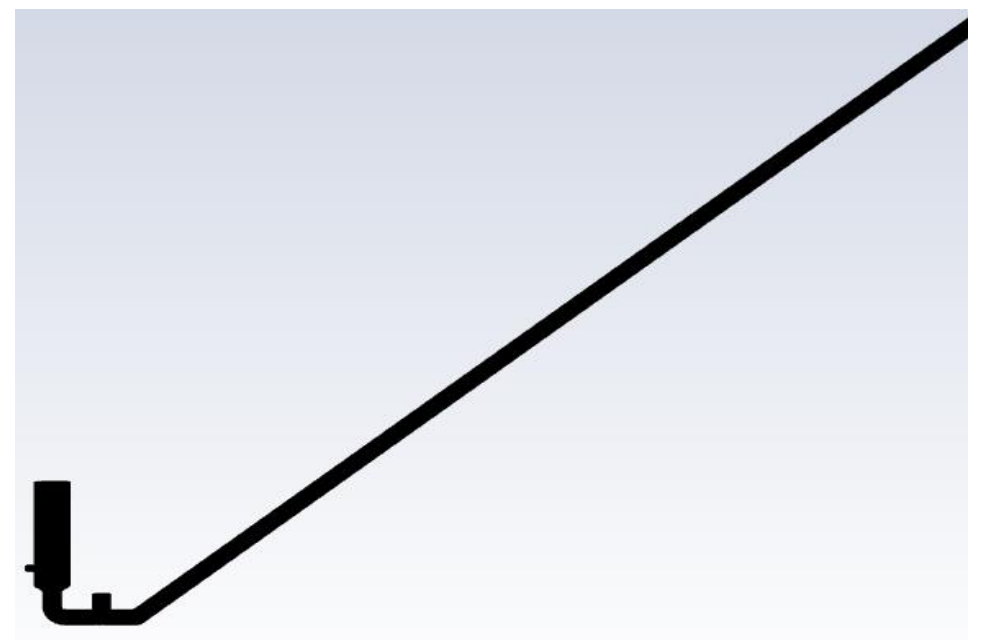

(a) 


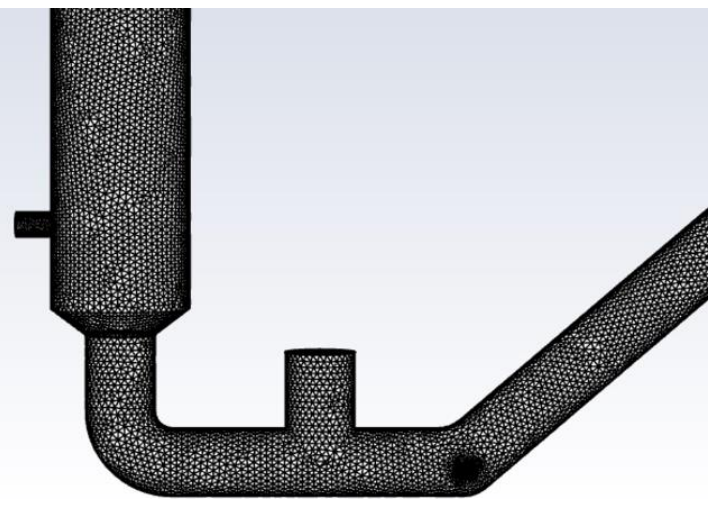

(b)

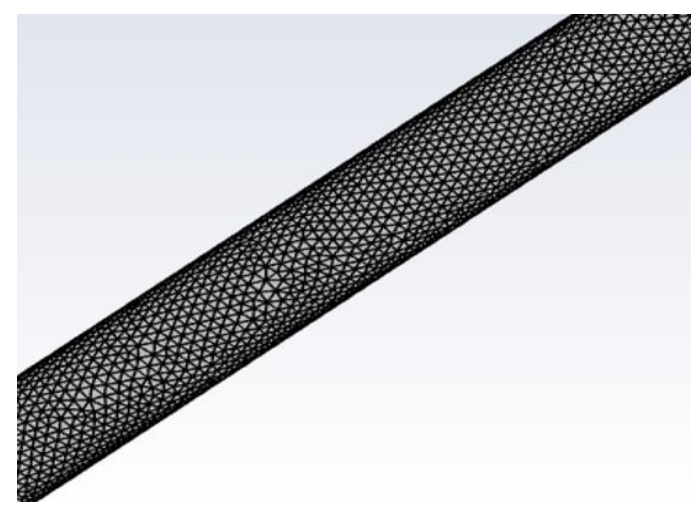

(c)

Gambar 2.2 (a) Mesh pada geometri keseluruhan, (b) Mesh pada pompa Hydram, (c) Mesh pada pipa pesat

Waktu simulasi yang digunakan pada penelitian adalah 4 detik yang mengacu pada pergerakan katup pengantar dan katup buang. Pergerakan maksimal dari katup pengantar yaitu setinggi satu $1 \mathrm{~cm}$ baik dalam kondisi terbuka maupun kondisi tertutup. Pergerakan maksimal pada katup buang yaitu setinggi $8 \mathrm{~cm}$ baik dalam kondisi terbuka maupun kondisi tertutup. Pergerakan katup pada pompa Hydram dijalankan menggunakan layering dynamic mesh dengan setting pergerakan menggunakan profile.

\section{Hasil dan Pembahasan}

Setelah proses simulasi dilakukan, tahap selanjutnya adalah post processing untuk memperoleh karakteristik aliran fluida pada pompa Hydram meliputi tekanan, kecepatan, streamline dan nilai force pada katup pengantar. Tekanan yang dihasilkan pada kondisi katup buang terbuka $8 \mathrm{~cm}$, badan pompa Hydram mengalami penurunan tekanan disebabkan oleh aliran fluida mangalami peningkatan seiiring katup buang terbuka. Tekanan pada tabung pompa Hydram terdistribusi rata tidak mengalami peningkatan diakibatkan oleh katup pengantar masih tertutup sehingga aliran ke tabung pompa Hydram masih mampat seperti yang ditunjukan pada gambar 3.1.
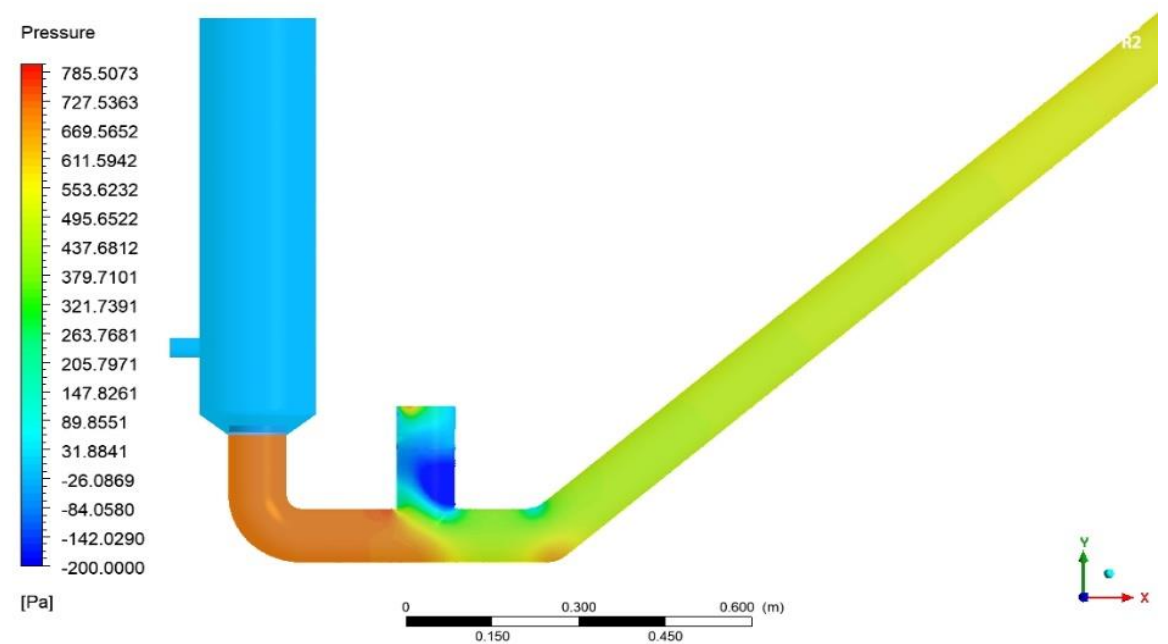

Gambar 3.1 Kontur tekanan pada tabung kondisi katup buang terbuka $8 \mathrm{~cm}$ 
Hasil simulasi pada gambar 3.2 kondisi katup pengantar terbuka $1 \mathrm{~cm}$ menunjukan peningkatan tekanan pada tabung pompa Hydram. Peningkatan tekanan pada tabung pompa Hydram disebabkan oleh kompresi saat katup buang tertutup, kemudian terjadi palu air yang menyebabkan katup pengantar terbuka. Katup pengantar terbuka menyebabkan tekanan pada badan pompa terdistribusi ke tabung pompa Hydram.

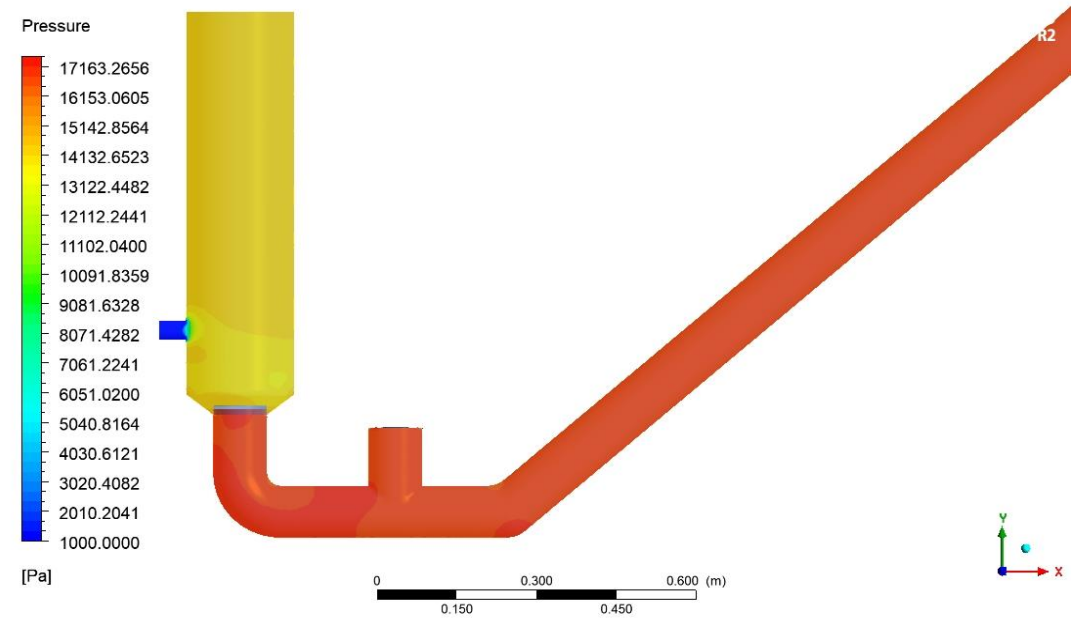

Gambar 3.2 Kontur tekanan pada Kondisi Katup Pengantar Terbuka $8 \mathrm{~cm}$

Hasil simulasi menunjukan bahwa kecepatan aliran pada pompa Hydram mengalami peningkatan hingga mencapai kecepatan maksimumya. Kecepatan aliran tersebut menghasilkan gaya dorong yang menyebabkan katup buang terbuka seiiring bertambahnya kecepatan aliran seperti ditunjukan pada gambar 3.3(a) kondisi katup buang terbuka $8 \mathrm{~cm}$.

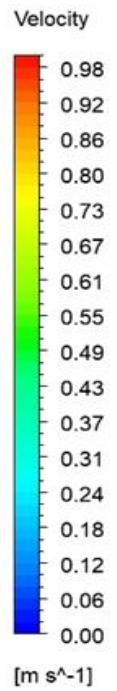

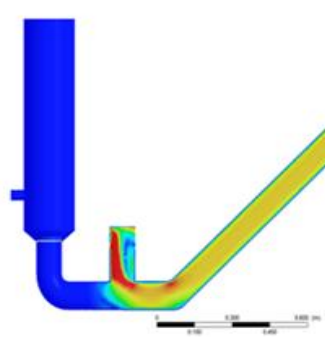

(a)

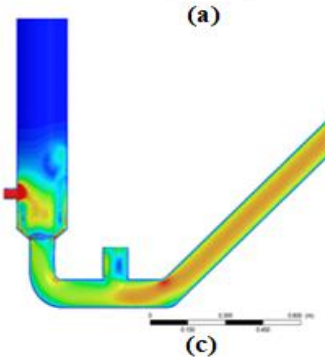

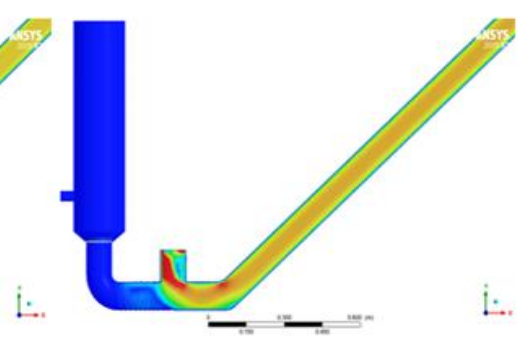

(b)
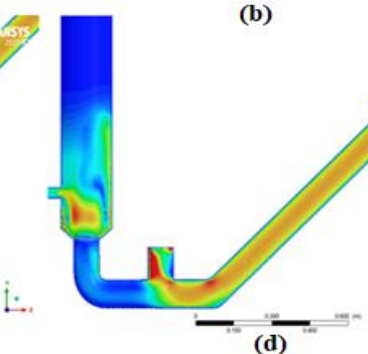

Gambar 3.3. Kontur tekanan pompa hydram pada kondisi (a). Katup buang terbuka $8 \mathrm{~cm}$, (b). Katup buatertutup $8 \mathrm{~cm}$, (c). Katup pengantar terbuka $1 \mathrm{~cm}$, (d). Katup pengantar tertutup $1 \mathrm{~cm}$

Katup buang terbuka (gambar 3.3(a)) menyebabkan tekanan pada badan pompa Hydram mengalami penurunan sehingga katup buang tertutup (gambar 3.3(b). Pada saat Katup buang terbuka dan sesaat kemudian kemudian katup buang tertutup terjadi kompresi yang menyebabkan katup pengantar terbuka seperti yang ditunjukan pada gambar 3.3(d) katup pengantar terbuka $1 \mathrm{~cm}$. 


\section{$\overline{\mathrm{n}}_{\text {Teknik }}^{\text {Tens }}$

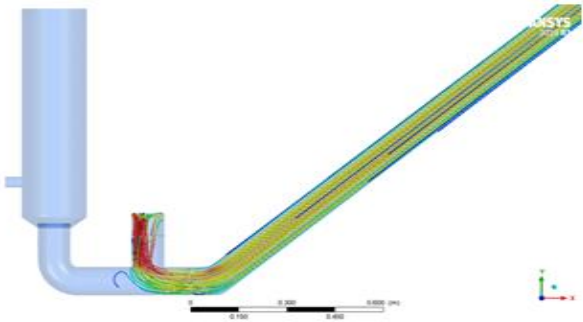

(a)

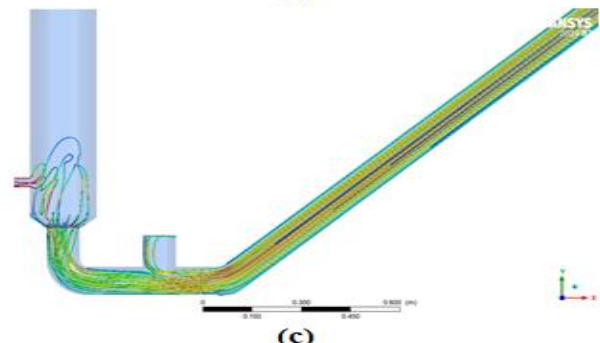

(c)

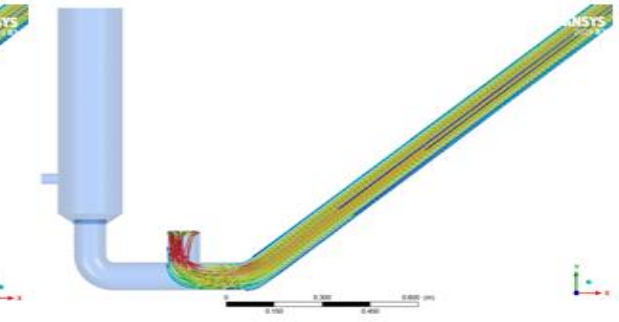

(b)

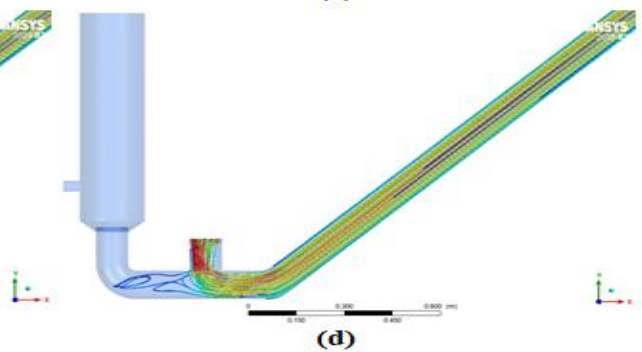

Gambar 3.4 Kontur streamline pada saat (a). Katup buang terbuka $8 \mathrm{~cm}$, (b). Katup buang tertutup 8 $\mathrm{cm}$, (c). Katup pengantar terbuka $1 \mathrm{~cm}$, (d). Katup pengantar tertutup $1 \mathrm{~cm}$.

Hasil simulasi pada gambar 3.4 menunjukan pergerakan fluida pada pompa Hydram yang di aplikasikan melalui streamline. Gambar 3.4 menggambarkan tentang pergerakan fluida mulai dari kondisi katup buang terbuka, katup buang tertutup, katup pengantar terbuka dan katup pengantar tertutup. Sehingga dapat dilihat dari hasil simulasi bahwa kecepatan dari aliran fluida tersebut yang menyebabkan katup buang dan katup pengantar terbuka.

Observasi lebih lanjut kemudian dilakukan dengan membuat kontur pada tiap bagian badan pompa Hydram dan tabung udara untuk mengetahui pengaruh kecepatan aliran terhadap tekanan yang dihasilkan. Gambar 3.5 dan gambar 3.6 memperlihatkan kecepatan aliran yang dihasilkan oleh pompa Hydram berbanding terbalik dengan tekanan. Hasil simulasi menunjukan bahwa pada saat katup buang terbuka kecepatan alirannya mengalami peningkatan dan tekanan yang dihasilkan mengalami penurunan secara bertahap.
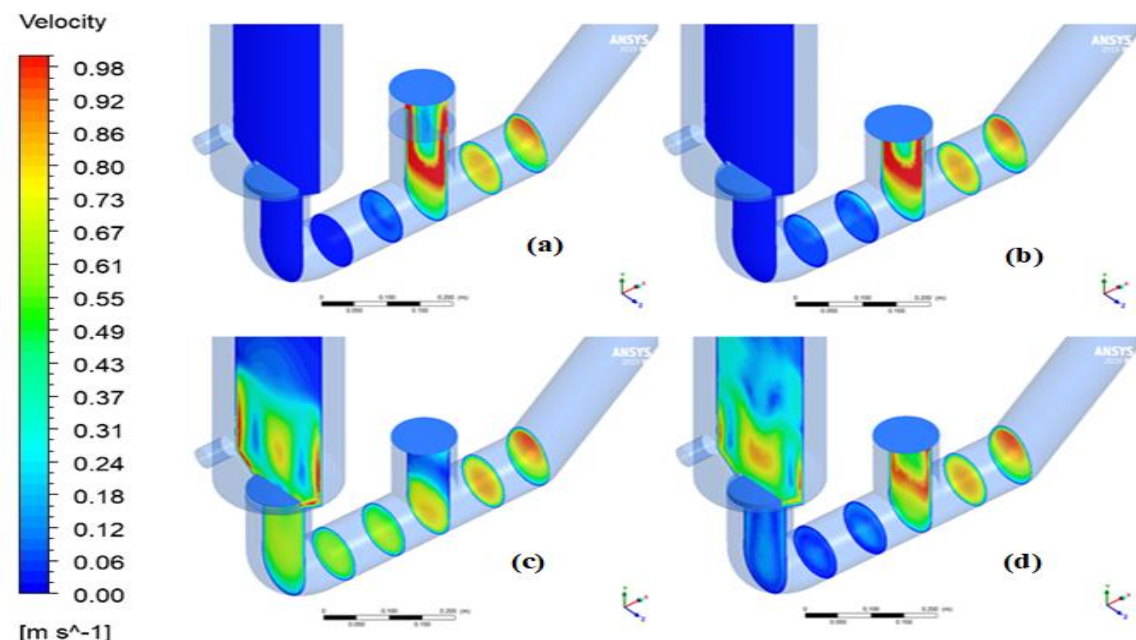

[m s^-1]

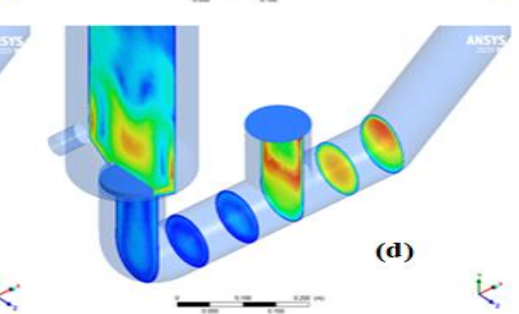

Gambar 3.5 Kontur kecepatan pada kondisi (a). Katup buang terbuka $8 \mathrm{~cm}$, (b). Katup buang tertutup 8 $\mathrm{cm}$, (c). Katup pengantar terbuka $1 \mathrm{~cm}$, (d). Katup pengantar tertutup $1 \mathrm{~cm}$.

Gambar 3.5 kondisi katup buang terbuka $8 \mathrm{~cm}$ terlihat bahwa kecepatan aliran kearah katup buang terjadi peningkatan kecepatan yang signifikan, sehingga dapat dilihat kecepatan aliran tersebut menghasilkan gaya dorong yang menyebabkan katup buang terbuka. Pada kondisi katup buang terbuka $8 \mathrm{~cm}$ menunjukan kecepatan nya mengalami peningkatan, kondisi tekanan yang dihasilkan mengalami penurunan seperti yang ditunjukan pada gambar 8 kondisi katup buang terbuka $8 \mathrm{~cm}$. 
(a)
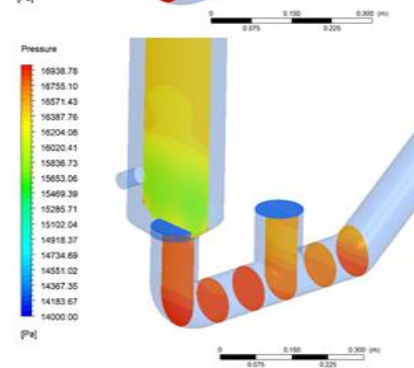

(a)

(c)

Li: ion
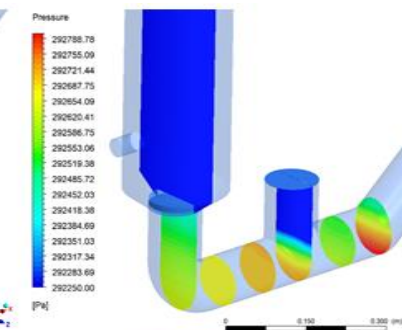

(b)
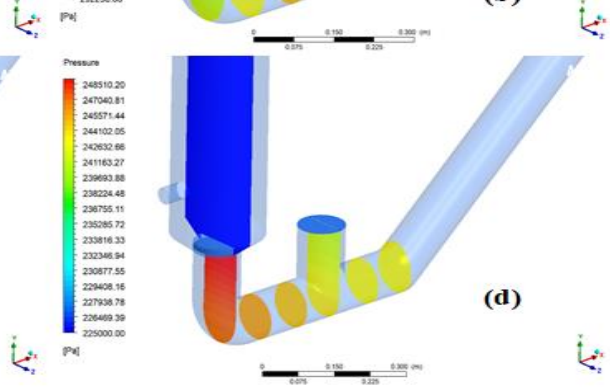

-

$<$

Gambar 3.6 Kontur kecepatan pada saat (a). Katup buang terbuka $8 \mathrm{~cm}$, (b). Katup buang tertutup 8 $\mathrm{cm}$, (c). Katup pengantar terbuka $1 \mathrm{~cm}$, (d). Katup pengantar tertutup $1 \mathrm{~cm}$.

Hasil simulasi pada gambar 3.5 dan gambar 3.6 menunjukan bahwa siklus pada pompa Hydram adalah peningkatan kecepatan aliran fluida, sehingga menyebabkan katup buang terbuka. Katup buang terbuka tekanan pada pompa Hydram mengalami penurunan sehingga katup limbah tertutup secara perlahan seperti yang ditunjukan pada gambar 3.6. Tekanan pada pompa Hydram mengalami peningkatan pada saat katup buang tertutup sehingga terjadi kompresi menyebabkan katup pengantar terbuka.

Hasil dari simulasi juga menunjukkan bahwa terjadi penurunan nilai force ketika katup pengantar pada pompa Hydram mulai mengalami pergerakan seperti yang ditunjukkan pada Gambar 3.7. Dari gambar ini dapat diketahui nilai force tertinggi terjadi pada saat katup pengantar mengalami pergerakan $0,1 \mathrm{~cm}$ sebesar $546,361 \mathrm{~N}$ dan nilai force terendah berada pada saat katup pengantar mengalami pergerakan sejauh $1 \mathrm{~cm}$ sebesar 135,467 N.

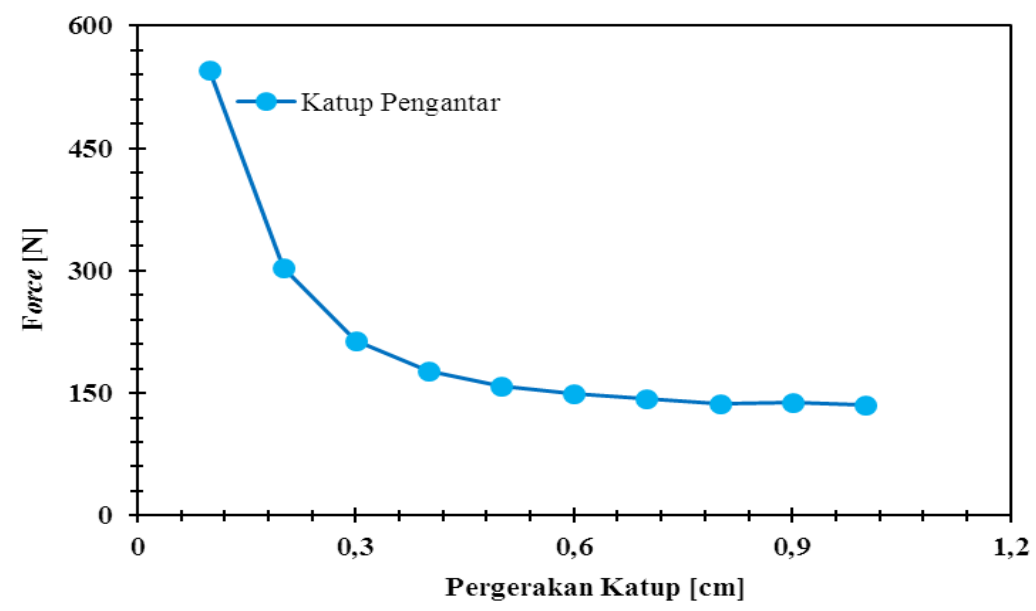

Gambar 3.7 Hubungan antara Force dan Pergerakan Katup Pengantar

Nilai force pada katup pengantar mengalami penurunan diakibatkan oleh pengaruh antara tekanan dan kecepatan aliran fluida. Tekanan pada badan pompa akan mengalami penurunan seiring terbukanya katup pengantar sehingga aliran fluida nya mengalami peningkatan menyebabkan nilai force pada katup pengantar mengalami penurunan. Nilai force yang dihasilkan oleh kecepatan aliran fluida digunakan untuk mengetahui pengaruh penerapan katup pengantar pada pompa Hydram. Tumbukan antara fluida yang mengalir 
dengan katup pengantar secara berulang-ulang akan mengakibatkan katup pengantar mengalami kerusakan. Nilai force ini bisa dijadikan acuan untuk memilih bahan yang tepat untuk pembuatan katup pengantar yang dapat menahan force maksimal yang ditimbulkan dari aliran fluida. Hal ini sesuai dengan penelitian sebelumnya, dimana Marbun \& Hazwi [2] simulasi CFD aliran fluida pada pompa Hydram dengan tinggi air jatuh 2,3 m dengan kondisi aliran steady, inkompresible, turbulen, geometri 3 tiga dimensi telah menghasilkan kesimpulan bahwa terdapat kesesuaian antara hasil simulasi CFD dengan eksperimen dengan tingkat kesalahan 0,78 \% sampai dengan 9,19\%. Di sisi lain, juga telah dilakukan studi komputasi yang menemukan bahwa aliran massa melalui katup limbah Hydram yang lebih banyak, akan mempengaruhi desain model pompa Hydram baru[3].

Peneliti sebelumnya telah melakukan eksperimen pada model pompa Hydram dengan variasi semua parameter katup limbah. Hasilnya menunjukkan bahwa semua parameter desain katup limbah seperti lubang katup dan diameter cakram, massa katup, dan stroke valve secara signifikan mempengaruhi kinerja sistem pompa ram hidrolik[12]. Selaras dengan penelitian tersebut, pemodelan matematis telah dikembangkan oleh Filipan (2003). Peneliti ini menyajikan pemodelan matematika dari pompa Hydram, sistem dan penjelasan siklus kerja yang disederhanakan. Aliran dalam sistem pompa Hydram tidak stabil, oleh karena itu persamaan aliran pipa tidak stabil dan metode karakteristik diberikan. Pemodelan matematika komponen tertentu dari sistem pompa Hydram dijelaskan secara rinci. Kondisi batas terdiri dari 11 persamaan dengan 11 variabel dependen dan diselesaikan dengan prosedur iteratif untuk setiap langkah waktu menjalankan komputasi. Model yang diturunkan diprogram untuk komputer digital. Simulasi komputer menggunakan data input dari literatur dibuat dan hasilnya disajikan dalam bentuk grafik tekanan dan kecepatan vs waktu[13].

\section{KeSIMPULAN}

Berdasarkan uraian dalam pembahasan dapat disimpulkan bahwa karakteristik aliran fluida yang terjadi pada pompa Hydram, termasuk kontur tekanan yang terjadi telah dihasilkan melalui simulasi CFD dan dibahas dengan menujuk pada penelitian sebelumnya. Salah satu hasil yang cukup memberikan informasi signifikan ialah bahwa tekanan di daerah badan pompa lebih tinggi daripada di daerah tabung, dimana perbedaan tekanan tersebut disebabkan oleh pergerakan katup dan diameter pipa yang berbeda. Kecepatan aliran yang terjadi sangat berpengaruh terhadap tekanan yang dihasilkan, sehingga pada saat kecepatan aliran fluida pada pompa Hydram mengalami peningkatan maka tekanan yang terjadi mengalami penurunan. Nilai force pada katup pengantar pompa Hydram mengalami penurunan seiiring dengan pergerakan katup. Nilai force tertinggi pada pergerakan katup 0,1 $\mathrm{cm}$ sebesar 546,361 $\mathrm{N}$ dan nilai force terendah berada pada saat katup pengantar mengalami pergerakan sejauh $1 \mathrm{~cm}$ sebesar 135,467 N. Hasil ini telah dibahas berdasarkan penelitian sebelumnya dan menunjukkan kesesuaian, minimal tidak ada yang bertentangan satu sama lain.

\section{UCAPAN TERIMA KASIH}

Terima kasih kepada Lembaga Penelitian Publikasi dan Pengabdian Kepada Masyarakat (LP3M) Universitas Muhammadiyah Yogyakarta yang telah mendanai kegiatan ini dan juga segenap tim pendukung teknis pengambilan data dan simulasi.

\section{Daftar Pustaka}

[1] Widarto dan Sudarto, Membuat Pompa Hidram. Kanisius, Jakarta, 1997.

[2] H. Marbun, M. H.- E-Dinamis, "Simulasi Aliran Fluida pada Pompa Hidram Dengan Tinggi Air Jatuh 2.3 M Dengan Menggunakan Perangkat Lunak CFD," Academia.Edu, 2013.

[3] P. Shende, S. C.-I. J. For,"Analysis And Enhancement of Hydraulic Ram Pump Using Computational Fluid Dynamics (Cfd)," Academia.Edu, 2015,

[4] P. Siahaan And T. Sitepu, "Rancang Bangun Dan Uji Eksperimental Pengaruh Variasi Panjang Driven Pipe dan Diameter Air Chamber Terhadap Efisiensi Pompa Hidram," J. Din., Vol. II, No. 12, 2013. 
[5] D. H. Efendi, M. Pd, B. Hapis Tambunan, And K. Person, "Pengaruh Volume Tabung Udara Terhadap Efisiensi Pompa Hidram", 2014.

[6] D. O. Panjaitan And T. Sitepu, "Rancang Bangun Pompa Hidram Dan Pengujian Pengaruh Variasi Tinggi Tabung Udara Dan Panjang Pipa Pemasukan Terhadap Unjuk Kerja Pompa Hidram," J. E-Dinamis, Vol. II, No. 2, 2012.

[7] A. Supriyanto, D. I.-T. J. P. S. Teknik, "Pengaruh Variasi Jarak Sumbu Katup Limbah Dengan Sumbu Tabung Udara Terhadap Efisiensi Pompa Hidram," Ojs.Ummetro.Ac.ld, 2017.

[8] D. S. Fane, R. Sutanto, And I. Made Mara, "Pengaruh Konfigurasi Tabung Kompresor Terhadap Unjuk Kerja Pompa Hidram," 2012.

[9] G. Prijo Utomo And E. Santoso, "Analisa Pengaruh Tinggi Jatuhan Air Terhadap Head Pompa Hidram," 2015.

[10] G. San, G. S.-J. T. Mesin,"Studi Karakteristik Volume Tabung Udara Dan Beban Katup Limbah Terhadap Efisiensi Pompa Hydraulic Ram," Ced.Petra.Ac.Id, 2002.

[11] B. Jimbaran And B. Abstrak, "Kajian Eksperimental Pengaruh Tabung Udara Pada Head Tekanan Pompa Hidram Made Suarda (1) Dan Ikg Wirawan (2)," 2008.

[12] M. Suarda, A. Ghurri, M. Sucipta, I. G. Bagus, And W. Kusuma, "Investigation On Characterization Of Waste Valve To Optimize The Hydraulic Ram Pump Performance," P. 20023, Vol. 1984, No.1. p 20023, 2018.

[13] V. Filipan, Z. Virag, A. B.-S. Vestnik J. Of Mechanical, "Mathematical Modelling Of A Hydraulic Ram Pump System," Bib.Irb. Hr, 2003. 